\title{
Main Areas of Internal Control for Independent Assessment of Tax Risks in Tax Consulting in the Digital Economy of Russia
}

\author{
Chechushkova O.N.
}

Ural State University of Economics post-graduate student of the Department of Finance, money circulation and credit, Director of LLC Scientific Association "Your Accountant"

e-mail: Chon74@mail.ru

\begin{abstract}
Thanks to the digital economy, there is an urgent need to transform an accountant into a tax consultant - to independently calculate tax risks and internal tax control systems, and this opportunity has appeared remotely and quickly to solve problems. Therefore, there is a demand for a new type of service - tax consulting. According to experts, all this has provoked an increase in demand for tax consulting, and the offer does not always meet the high requirements of professionalism in this area. The problem is solved by the main directions of internal control methods considered in the article for independent assessment of tax risks at the enterprise, based on internal control and Tax Legislation requirements. The analysis of the state control system is presented.
\end{abstract}

Keywords: digital economy, tax risks, tax consulting, publicly available criteria for independent assessment of tax risks, internal control methods

\section{INTRODUCTION}

The state has made it mandatory to use the digital economy by creating a number of amendments - including the mandatory submission of VAT returns electronically, and the creation of an electronic signature. Since July 1, 2015, in accordance with Federal law No. 347-FZ of 04.11.2014 for taxpayers, relevant amendments have been made to the Tax code of the Russian Federation and the electronic service "taxpayer's Personal account" has received the official status of an information resource that can be used for taxpayers and tax authorities to exercise their rights and obligations. Creating electronic reporting, the system of "ask VAT-2" VAT verification, the Provision on reliability and self-checking of tax risks (creating a portal), plus the introduction of criminal liability for tax offenses. Taxpayers are increasingly facing unplanned tax risks that lead to bankruptcy and criminal liability. This is because the transaction is considered fictitious due to an unreliable supplier, the purchase amount is removed from expenses and taxes are charged before. If the company is not able to pay taxes, the way out in this situation is increasingly bankruptcy. Thanks to the digital economy, there is an urgent need to transform an accountant into a tax consultant-to independently calculate tax risks and internal tax control systems, and this opportunity has appeared remotely and quickly to solve problems. In such a situation - the development of the digital economy - you can not do without professionals (usually a team of professionals) - tax consultant. Practice shows that the accountant does not have enough knowledge and practice on tax accounting and his work is aimed at solving a narrow focus - it is the solution of everyday tasks in the company: it is the issuance of salaries to employees, the shipment of goods, the arrival of goods, etc. There is no time left to optimize tax accounting, and there is not enough knowledge, and there is no personal interest. Therefore, there is a demand for a new type of service - tax consulting. According to experts, all this has provoked an increase in demand for tax consulting, and the offer does not always meet the high requirements of professionalism in this area, so there is a type of exclusive tax consultants, as a rule, they are concentrated in Moscow, whose cost of services is highly inflated for an ordinary entrepreneur from the region. And the problem needs to be solved? I propose to consider the main methods for self-assessment of tax risks on enterprises based on internal control.

\section{RESEARCH METHODOLOGY}

The main common type of tax consulting is tax optimization, which consists of tax planning, tax regulation and internal tax control. All this is a management activity: "it allows not only to reduce the tax burden in a short-term situation, but also to ensure longterm savings on taxes, to get additional economic effect, to 
avoid or reduce the risk of possible penalties in the future" [1].

When optimizing taxes, we should not forget about the requirements of the state imposed on taxpayers in order to independently determine tax risks - this is the Order of the Federal tax service of Russia from 30.05.2007 N MM-306/333@ (ed. from 10.05.2012) "Publicly available criteria for independent risk assessment for taxpayers", which presents the criteria of tax authorities for selecting objects for on-site tax audits":

"When an assessing tax risk that may be associated with the nature of relationships with certain counterparties, the taxpayer is recommended to investigate the following features:

- absence of personal contacts between the management (authorized officials) of the supplier company and the management (authorized officials) of the buyer company when discussing the terms of delivery, as well as when signing contracts;

- absence of documentary confirmation of the authority of the head of the counterparty company, copies of the identity document;

- absence of documentary confirmation of the authority of the counterparty's representative, copies of the identity document;

- lack of information about the actual location of the counterparty, as well as the location of warehouse and / or production and / or retail space;

- the lack of information about how to obtain information about the counterparty (there is no advertising in the media, there is no recommendations of the partners or other persons, no website contractor, etc.). The negativity of this sign is compounded by the availability of information (e.g., media, outdoor advertising, Internet sites, etc.) on other market participants (including manufacturers) are identical (similar) goods (works, services), including offering its goods (works, services) at lower prices;

- lack of information about the state registration of the counterparty in the USRLE [2].

The presence of such signs indicates a high degree of risk of qualification of such a counterparty by the tax authorities as problematic (or "one-day"), and transactions made with such a counterparty are questionable"[2].

Using such contractors, the penalty falls on the client in VAT, this is an unjustified benefit - an understatement of the tax base. All purchases under this contractor shall be cancelled and the customer increases the tax base, this measure was introduced relatively recently and is yielding positive results. "We can conclude that the state has built a clear sequence of actions aimed at collecting tax obligations at any cost - any non-payment of taxes entails the duty of the tax authorities to describe the intent, which in the case of non-payment is the basis for initiating criminal proceedings. The fact of the initiated case is the basis for bringing to subsidiary liability the founder, the management of the company controlling the debtor's business, nominee managers under article 1064 of the GKRF, and if they do not have the necessary resources, recovery at the expense of the property of relatives. In parallel, the amounts of tax arrears are collected under article 45 of the tax code from related parties. The existing panacea in the form of bankruptcy was transformed into an aggravating circumstance for the founders, controlling persons"[3].

The main criteria that taxpayers should follow are the requirements of the tax authorities themselves, which are presented in the tax code. Table 1 shows all the criteria for tax risks related to the taxpayer's performance presented by the state in the tax code of the Russian Federation.

An economic entity or an individual who is not registered as such may also be held criminally liable for tax crimes under 6 articles of the Criminal code, namely, article 198 to article 199.4. Each of them corresponds to a separate type of crime:

- $\quad$ article 198 - evasion of taxes and contributions by an individual entrepreneur or a citizen not registered as an individual entrepreneur;

- $\quad$ article 199-tax avoidance by a legal entity;

- $\quad$ article 199.1-ignoring by the agent for transfers to the budget of its duties;

- $\quad$ article 199.2-concealment of money and other assets that can be used to collect debts on payments to the budget;

- $\quad$ article 199.3-evasion of payment of contributions to the FSS for injuries to an individual entrepreneur or an individual who is not registered as an individual entrepreneur;

- article 199.4-avoiding the payment of contributions to the FSS for injuries by the organization.

The act committed by the defendant may entail criminal liability for violation of tax legislation in accordance with these articles, only if the court has established the intent of the crime (paragraph 8 of the resolution of the Plenum of the Supreme court of the Russian Federation of 28.12.2006 No. 64).

The main types of punishments provided for in the abovementioned articles of the Criminal code:

- penalty;

- disqualification;

- forced labour;

imprisonment. 
Table 1 Criteria for tax risks of organizations presented by the state in the tax code of the Russian Federation.

\begin{tabular}{|c|c|c|c|}
\hline Criteria & $\begin{array}{l}\text { Article of the tax code of the } \\
\text { Russian Federation }\end{array}$ & State tax risk & Taxpayer's fine \\
\hline $\begin{array}{l}\text { Violation of the procedure for } \\
\text { registration with the tax } \\
\text { authority. }\end{array}$ & $\begin{array}{l}\text { clause } 1 \text { of article } 23- \\
\text { obligation, } \\
\text { clause } 5 \text { of article } 3 \\
\text { responsibility, article 116- } \\
\text { specifies responsibility }\end{array}$ & $\begin{array}{l}\text { Inability to control activities } \\
\text { and failure to receive tax } \\
\text { payments }\end{array}$ & $\begin{array}{l}10,000 \text { rubles-violation of the } \\
\text { deadline } \\
10 \% \text { of revenue, at least } 40,000 \\
\text { rubles }\end{array}$ \\
\hline Failure to submit a tax return & $\begin{array}{l}\text { clause } 1 \text { of article } 23- \\
\text { obligation, clause } 5 \text { of article } \\
23 \text {, article } 119 \text { responsibility }\end{array}$ & $\begin{array}{l}\text { Inability to control activities } \\
\text { and lack of access to tax } \\
\text { payments }\end{array}$ & $\begin{array}{l}5 \% \text { of the unpaid tax amount for each } \\
\text { month, but no more than } 30 \% \text { and no } \\
\text { less than } 1,000 \text { rubles }\end{array}$ \\
\hline $\begin{array}{l}\text { Violation of the established } \\
\text { method for submitting a tax } \\
\text { return }\end{array}$ & $119.1,119.2$ & $\begin{array}{l}\text { Inability to control activities } \\
\text { and lack of access to tax } \\
\text { payments }\end{array}$ & $\begin{array}{l}200 \text { rubles - non-compliance with the } \\
\text { order } \\
40,000 \text { rubles - for false information } \\
80,000 \text { rubles - intentional acts }\end{array}$ \\
\hline $\begin{array}{l}\text { Gross violation of the rules for } \\
\text { accounting of income and } \\
\text { expenses and objects of taxation }\end{array}$ & $\begin{array}{l}\text { section } 1 \text { of article } 23 \text { of the } \\
\text { tax code - the duty to keep } \\
\text { records in the prescribed } \\
\text { manner, fix in Bank and cash } \\
\text { documents are not allowed, } \\
\text { and the rest on agreement } \\
\text { between the participants of } \\
\text { economic activities, clause } 3 \text {, } \\
\text { article } 120 \text { is a gross violation } \\
\text { of accounting rules - the lack } \\
\text { of primary documents, clause } \\
5 \text {, article } 23 \text { of the tax code, } \\
\text { article } 120 \text { of the tax code - } \\
\text { responsibility }\end{array}$ & & $\begin{array}{l}10,000 \text { rubles- an offense for a year, } \\
30,000 \text { rubles - more than one year, } \\
\text { understatement of the tax base - } 20 \% \\
\text { of the amount of unpaid tax, not less } \\
\text { than } 40,000 \text { rubles }\end{array}$ \\
\hline $\begin{array}{l}\text { Non-payment or incomplete } \\
\text { payment of the tax amount }\end{array}$ & $\begin{array}{l}\text { article } 23 \text {, paragraph } 1 \text {, of the } \\
\text { tax code, article } 23 \text {, paragraph } \\
5-\text { liability, article } 122 \\
\text { specifies }\end{array}$ & & $\begin{array}{l}20 \% \text { of the unpaid tax amount, } \\
\text { intentional actions } 40 \%\end{array}$ \\
\hline $\begin{array}{l}\text { Non-transfer of tax by a tax } \\
\text { agent }\end{array}$ & $\begin{array}{l}\text { clause } 1 \text { of article } 23 \text { of the tax } \\
\text { code of the Russian } \\
\text { Federation, clause } 5 \text { of article } \\
\text { 24-liability, article } 123 \\
\text { specifies }\end{array}$ & & $20 \%$ of the unpaid tax amount \\
\hline $\begin{array}{l}\text { Non-compliance with the order } \\
\text { of possession of property that is } \\
\text { subject to seizure or bail }\end{array}$ & $\begin{array}{l}\text { Article } 77 \text { of the tax code, } \\
\text { liability of article } 125 \text { of the } \\
\text { tax code }\end{array}$ & & 30,000 rubles \\
\hline $\begin{array}{l}\text { Failure to provide the tax } \\
\text { authority with information } \\
\text { required for tax control }\end{array}$ & $\begin{array}{l}\text { p. } 1,2 \text { of article } 23 \text {, article } 93- \\
\text { duty within } 10 \text { days, article } \\
126,135 \text { responsibility }\end{array}$ & & $\begin{array}{l}200 \text { rubles for each document, if } \\
\text { rejected }-10,000 \text { rubles. LLC or sole } \\
\text { proprietor, with a price of } 1,000 \\
\text { rubles }\end{array}$ \\
\hline $\begin{array}{l}\text { Unlawful failure to provide } \\
\text { information to the tax authority }\end{array}$ & $129.1,126$ & & 5000 rubles, repeated 20,000 rubles \\
\hline $\begin{array}{l}\text { Non-payment or incomplete } \\
\text { payment of tax on controlled } \\
\text { transactions that are not related } \\
\text { or incompatible commercial } \\
\text { terms } 105.15\end{array}$ & 129.3 & & $\begin{array}{l}40 \% \text { of the unpaid amount, but not } \\
\text { less than } 30,000 \text { rubles. }\end{array}$ \\
\hline $\begin{array}{lrrr}\text { Unlawful failure } & \text { to } & \text { provide } \\
\text { notification } & \text { of } & \text { controlled } \\
\text { transactions } & \text { or } & \text { false } \\
\text { information } & & & \\
\end{array}$ & 129.4 & & 5,000 rubles \\
\hline
\end{tabular}

\section{RESEARCH RESULT}

Speaking of internal tax control, we can not fail to mention the work of the state control over VAT, which began several years ago and is being implemented in stages - this system of "ASK VAT-2" and has positive results for the state in practice. So, if you look at the trend in tax collection has a positive dynamics-shown in table 2 . 
Table 2 Receipts by type of tax to the consolidated budget of the Russian Federation 2018-2019 data taken https//:налог.py

\begin{tabular}{|c|c|c|c|}
\hline \multirow{2}{*}{ type of taxes } & \multicolumn{3}{|c|}{ billion rubles } \\
\hline & 2018 & 2019 & pace, $\%$ \\
\hline extraction tax & 6127,4 & 6106,4 & $-99,7$ \\
\hline Profit tax & 4100,04 & 4543,1 & 110,8 \\
\hline VAT & 3574,6 & 4257,8 & 119,1 \\
\hline Personal income tax & 3653 , & 3955,2 & 108,3 \\
\hline Property taxes & 1396,8 & 1350,8 & $-96,7$ \\
\hline Excises & 1493,2 & 1277,5 & $-85,6$ \\
\hline Total & 20343 & 21488 & \\
\hline The share of VAT & 17,57 & 19,02 & \\
\hline The share of profit & 20,16 & 21,15 & \\
\hline
\end{tabular}

Thus, for the receipt of VAT and profit Tax in the budget in comparison with other taxes is the highest, if you do not take into account taxes from the earth's interior. If we take all industries, the income tax revenue to the budget in 2018 amounted to $4,100.04$ billion rubles this is $20.16 \%$ of the total amount of taxes and $17.57 \%$ VAT, this is noticeable for businesses. I would like to note the indicators of accrual of tax revenues to the budget: received in 2018. 21148.84 billion rubles, and accrued 20979.36 billion rubles, the amount of receipts is more than 169.48 billion rubles. RUB, which indicates the improvement of the state's control system. This is confirmed by the indicators of control work of tax authorities, presented in table 3.

Table 3 Data from statistical tax reporting forms 2-tax code of the Russian Federation for 2016-2019 in Russia as a whole. Report on the results of control work of tax authorities on the website of the Federal tax service in millions of rubles

\begin{tabular}{|l|l|l|l|l|}
\hline \multicolumn{1}{|c|}{ Checks } & $\mathbf{2 0 1 6}$ & $\mathbf{2 0 1 7}$ & $\mathbf{2 0 1 8}$ & $\mathbf{2 0 1 9}$ \\
\hline Desk checks organization checks in pieces line 3010 & 39984748 & 55859903 & 67889283 & 62802102 \\
\hline of them: detected violations in pieces line 3020 & 2254874 & 3014252 & 353116 & 2447065 \\
\hline $\begin{array}{l}\text { Additional payments accrued (including tax } \\
\text { penalties and penalties) Desk checks, thousand } \\
\text { rubles line 3060 }\end{array}$ & 98485375 & 61599442 & 55631081 & 37743893 \\
\hline $\begin{array}{l}\text { Total - field checks of organizations line in pieces } \\
3045\end{array}$ & 22602 & 17564 & 12542 & 8245 \\
\hline $\begin{array}{l}\text { Ad these, the number of detected line is pieces 3046 } \\
\text { penalties and penalties) on-site inspections, } \\
\text { thousand rubles line 3060 }\end{array}$ & 22410 & 17338 & 12271 & 7909 \\
\hline
\end{tabular}

\section{DISCUSSION OF RESULTS}

In the presented table, from 2016 to 2019 , there is an increase in the number of Desk checks, and the detected violations are decreasing. This means: improving the quality of independent control of taxpayers through electronic reporting and automation, which simplifies the procedure for submitting and self-checking reports. In
2016, the largest amount of additional charges as a result of in-house inspections was $98,485,375$ thousand rubles, and in 2019 - 37,743,893 thousand, a decrease of $60,741,482$ thousand rubles, although the number of inhouse inspections increased by 22,818 - from 39984 thousand rubles. in 2016, and in 2019 - 62,802 thousand, 
method: "it does not adequately take into account the real tax burden on enterprises, it is distorted under the influence of a narrow departmental approach. Customs duties, accrued insurance premiums and social funds are not taken into account, and indirect VAT is not included in costs "[5]. Davletshin T. G. suggests including VAT in the calculation of the tax burden, the VAT load increases the overall load on the example of the construction industry by $5.2 \%$. VAT cannot be ignored when calculating the tax burden of an enterprise, because its revenues are significant both for the budget and for the enterprise. Therefore, this control method is not a complete and sufficient tool for preventing internal tax risks. Therefore, we still need to pay attention to the methodology of the main common directions for reducing the tax liabilities of each tax separately, which can lead to aggressive policies and high tax risks. Let's look at the main trends in changes in tax liabilities that allow us to identify independently high tax risks, presented in table 4.

Table 4 The direction of change of tax obligations

\begin{tabular}{|c|c|c|c|}
\hline \multicolumn{2}{|c|}{ Without external drastic changes } & \multicolumn{2}{|c|}{ External change } \\
\hline Method & Method content & Method & Method content \\
\hline The reduction of the tax base & $\begin{array}{l}\text { Change of accounting } \\
\text { policy selection of } \\
\text { different methods of } \\
\text { accrual of income and } \\
\text { expenses - cash or accrual } \\
\text { method, cost write-off } \\
\text { methods, depreciation } \\
\text { methods. } \\
\text { Changes in pricing policy, } \\
\text { transfer pricing. Change of } \\
\text { contractual relations, use } \\
\text { of leasing. } \\
\text { Use of outstaffing and } \\
\text { outsourcing of services } \\
\text { reduction of Pension taxes. }\end{array}$ & Reducing the amount of taxes & $\begin{array}{l}\text { Changing the form of a legal } \\
\text { entity }\end{array}$ \\
\hline Reducing tax rates & 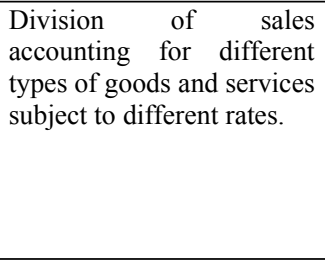 & The change in the tax regime & $\begin{array}{l}\text { Depending on the type of cash and } \\
\text { non-cash payment and type of } \\
\text { goods, services division mode, the } \\
\text { use of the simplified taxation } \\
\text { system, Single tax on imputed } \\
\text { income, Single agricultural tax. } \\
\text { The agreement on production } \\
\text { section }\end{array}$ \\
\hline Use of benefits and deductions & $\begin{array}{l}\text { Use of statutory benefits } \\
\text { and deductions. Changing } \\
\text { activities for preferential } \\
\text { taxation, using for example } \\
\text { exports, disabled people, } \\
\text { etc }\end{array}$ & $\begin{array}{l}\text { Change of place of } \\
\text { registration, use of } \\
\text { preferential goods, activities }\end{array}$ & $\begin{array}{l}\text { Offshore registration abroad, in } \\
\text { the free economic zone of the } \\
\text { Russian Federation, in another } \\
\text { zone with preferential taxation, } \\
\text { use of preferential goods, } \\
\text { activities, employees from socially } \\
\text { vulnerable segments of the } \\
\text { population (disabled, retired) } \\
\text { without documentary confirmation }\end{array}$ \\
\hline The terms of payment of taxes & $\begin{array}{l}\text { Use of deferral, according } \\
\text { to the tax code of the } \\
\text { Russian Federation or } \\
\text { delay time artificially, } \\
\text { intentional delay of } \\
\text { payment }\end{array}$ & $\begin{array}{l}\text { A written application for } \\
\text { deferred payment to the tax } \\
\text { authority, the ability to pay in } \\
\text { installments (VAT), obtaining } \\
\text { an overdraft from a servicing } \\
\text { Bank, and intentionally } \\
\text { submitting an empty } \\
\text { Declaration until the situation } \\
\text { improves }\end{array}$ & $\begin{array}{l}\text { Change the time of payment, } \\
\text { delay }\end{array}$ \\
\hline
\end{tabular}




\section{CONCLUSIONS}

The main task of entrepreneurs today is to reduce taxes and, as a rule, mainly by aggressive methods. This leads to unjustified tax risks, which leads to bankruptcy and destruction of the business, and criminal penalties. The company's administration does not have enough knowledge, and it is expensive to hire a specialist. Therefore, there are consultants who for a small fee only worsen the situation in the firm, which leads to bankruptcy. This outcome is also influenced by the lack of licensing of tax consulting and the mentality of shadow business in Russia, which often leads to aggressive methods of tax evasion and, as a result, gross violations of tax legislation and "unsatisfactory tax administration practices" [7]. This opinion is held by such scientists: Shevelev A.V., Malkina M. Yu., Davletshin T. G., Denisova I. P., Rukina S. N., Shchepotev A.V. Kirienko A. P., Orlova E. N., Bazhenova V. I. Pyshkina N. L., Yakushev M. F., and others.

\section{REFERENCES}

[1] Pimenov, N. A. Tax management: textbook for academic baccalaureate / N. A. Pimenov, D. G. Rodionov; responsible editor N. A. Pimenov. Moscow: Yurayt publishing house, 2019. - 305 p. (Bachelor's degree. Academic course).

[2] Order of the Federal tax service of Russia from 30.05.2007 N MM-3-06/333@ (ed. from 10.05.2012) http:/www.consultant.ru/cons/cgi/online.cgi?

req $=$ doc $\&$ base $=$ LAW $\& \mathrm{n}=129610 \&$ fld $=134 \& \mathrm{dst}=10000$ $1,0 \& \mathrm{rnd}=0.09851471915697352 \# 082529925294843$

[3] Ryakhovsky D. I., Baburyan L. M. Transformations of tax legislation as an element of tax consulting development in the digital economy / /(109) UEX, 3/2018 http://uecs.ru/uecs-109-1092018/item/48132018-03-07-12-06-56 https://www.rbc.ru/economics/ 24/06/2019/5d0cf3fc9a7947ccc62515b9

[5] Davletshin T. G. reformation of VAT and taxation of the construction industry / / Finance and credit. 2019. - Vol. 25, No. 2. - P. 458-479.

[6] Malkina M. Yu., Balakin R. V. Analysis and modeling of VAT receipts for regions of the Russian
The main methods of tax control proposed by the law are mainly devoted to the analysis of collection and are "expert in nature" [6], and the method of detecting violations and preventing them on the ground - this is given little attention in the special literature. To successfully implement internal control methods to prevent errors within the organization, you need to combine many practical tasks, starting from the prevention and detection of errors and methods of calculating each tax separately and the main recommendations of the Ministry of Finance to reduce tax risks, which lead to aggressive optimization methods. This includes studying the practice of errors in submitting tax reports, and the study of errors in calculating taxes and filling in returns, practice in tax disputes, responses to claims, knowledge of the tax code itself, and its constant changes, knowledge of modern computer technologies, which confirms the opinion that now is the time: "exclusive tax consultants".

Federation// Taxes and taxation. - 23(599). -2014. C1828

[7] Bogataya I. N. Features of tax consulting in the conditions of digitalization / / Collection: Development of Finance, accounting and audit in modern management concepts Materials of the I international scientific and practical conference.- 2018. - Pp. 15-19.

[8] Nechaeva M. L., Lysova E. A. System of financial control in the management of small business enterprises: methods and tools for implementation / / Finance and credit. - 2019. - Vol. 25, No. 2. - Pp. 360374. https://doi.org/10.24891/ fc. 25.2 .360

[9] Yurieva L. V., Sukhoi V. S. Internal audit and its relationship with the organization's internal control system: the problem of identification and international experience// Urfu Bulletin. Economics and management series.- 2015. - Vol. 14, No. 4., Pp. 624-641. DOI :10.15826/vestnik. 2015. 14. 4. 036

[10] Shchepotev A.V. Influence of the financial indicator "tax burden" on the definition of tax risks / / Financial Analytics: problems and solutions. - 2019. Vol. 12, No. 2. - P. 234-244. https://doi.org/10.24891/ fa. 12.2 .234 